Revista Brasileira de Odontologia Legal - RBOL

\title{
Forensic Odontology
}

\section{EXPLORING BITE MARKS ON DIFFERENT TYPES OF SKIN TONES.}

\section{Explorando as marcas de mordida em diferentes tipos de tons de pele.}

\author{
Uttara DESHPANDE ${ }^{1}$, Scheila MÂNICA ${ }^{1}$. \\ 1. Centre for Forensic and Legal Medicine and Dentistry, University of Dundee, Scotland, UK.
}

\begin{tabular}{ll}
\hline Information about the manuscript & Corresponding author: \\
Received in: 10 Feb 2019 & Uttara Deshpande \\
Accepted in: 09 Apr 2019 & 'Rajtara Complex'. Pune-Solapur highway, Manjri Bk, \\
& Pune-412307, India. \\
& Email: deshpandeuttara45@gmail.com.
\end{tabular}

\begin{abstract}
ASTRACT
The analysis of bite marks is a challenging and convoluted part of Forensic Odontology. Various interrelated factors such as location of the bite and skin elasticity complicate the bite mark analysis. The relationship between the bite mark and the biochemical properties of skin has been well-documented but there is need to consider the variety of skin tones as a factor to explore. The aim of this pilot study was to analyse the appearance of bite marks on 5 different types of skin tones of 15 subjects ( 6 males and 9 females) from 11 nationalities and age ranged from 21 to 46 years. A pair of 3D printed dental cast was transferred onto a mechanical apparatus for production of experimental bitemarks by using $12.5 \mathrm{~kg}$ of weight. Common imaging modalities including conventional, infrared and ultraviolet light were used to record the bite mark images for following visual assessment. The different skin tones were categorized using Fitzpatrick scale (1975) and a colour chart was used to compare the changes on skin after 15 minutes of bite registration. According to the results, the force was well tolerated by the subjects producing a well-defined bite mark, although males showed a less prominent mark than females irrespective of the skin tone and nationality. Neither bruises nor significant changes in the colour of bite mark could be appreciated among the subjects. The different types of skin tones did not affect the registration of bite mark applying a force of $122.5 . \mathrm{N}$ for 15 seconds in this sample.
\end{abstract}

\section{KEYWORDS}

Forensic odontology; Bite mark; Skin tones.

\section{INTRODUCTION}

Bite marks are often observed in sexual and physical assault cases on the skin of the victims. This piece of evidence is generally ignored, but if effectively recorded and investigated, bite marks may prove usefulness in investigating possible criminals ${ }^{1}$. The challenging task in forensic dentistry is the distortion of bite marks on the human skin $^{2}$. Skin as a bite registration material is highly variable in terms of underlying musculature, fat, curvature and looseness or adherence to underlying tissue. Also, it is highly visco-elastic and permits stretching, distorting under pressure and shrinking back to their original position ${ }^{3}$. The skin tone is determined by a pigment called melanin present in different types, being eumelanin the most common. The total melanin content in the epidermis varies by approximately just two-fold in Asian and White skin whilst Black skin has greater 
levels of melanin that is approximately threeto six-fold higher, with more of eumelanin than fair skin $^{4}$. Bruising appears more easily on the paler skin and if the skin is loose at the site of injury, bruising will occur more easily; conversely, if the skin is strongly supported and muscle tone is good, bruising may be minimal ${ }^{5}$. Accurate images of human bite marks are particularly important since the analysis is dependent on how skilfully the photographic images of the injury are recorded. $^{6}$ Moreover, additional imaging modalities such as infra-red (IR) and ultraviolet (UV) light can be used to enhance forensic analysis potential ${ }^{7}$.The longer wavelengths of IR light may provide additional information about injuries below the surface of the skin, as they can penetrate relatively deeper in the layers. The shorter wavelengths of UV light into human skin results in greater surface detail because of the superficial penetration. UV images may be able to reveal old injuries ${ }^{8}$. Since bite mark on different types of skin tones is not well-documented, this pilot study aimed to explore bite marks produced on different skin tones of subjects with assorted nationality, sex and age using three different imaging modalities.

\section{MATERIALS AND METHODS}

This study was ethically approved by the Research Ethics Committee of Schools of Nursing \& Health Sciences and Dentistry, University of Dundee, Scotland (application number: 2017009_Deshpande). The sample comprised of 15 subjects ( 6 males and 9 females) from 11 ancestries and age ranged from 21 to 46 years. The Fitzpatrick scale $^{4}(1975)$ composed of six types of skin tones (from I to $\mathrm{VI}$ ) was used to categorize the subjects: 3 subjects for each skin tone (I, II, II, IV, VI) but type V was excluded because subjects of this type of skin tone were not found as seen on table 1.

Upper and lower alginate (Unodent Exact Alginate Mint, Essex, England) impressions of one of the authors were taken along with a facebow recording and an occlusal record. After scanning the impressions, dental casts were created using a 3D printing material (NextDent, London, England) and articulated on a semiadjustable articulator (DenarMK $\| \circledast$, Prestige dental, Bradford, England). This articulator was transferred onto a mechanical apparatus for production of experimental bitemarks ${ }^{9}$. The articulated casts were placed within the frame under the rod allowing a load to be applied to the cast. Two weight plates of $5 \mathrm{~kg}$ and one of $2.5 \mathrm{~kg}$ respectively were used for production of test bites on the forearm of subjects as seen in figure 1.

The fore arm of each subject was measured from the point closest to the bony prominence of the elbow to the distal end of the radius. The length was divided into 3 equal parts and the site of the bite should be the middle third of the fore arm. Experimental bite mark was produced using $12.5 \mathrm{~kg}$ placed on the top of the rod for 15 seconds. Immediately after the bite was inflicted, the ABFO No.2 scale was placed framing the bite mark and photographs using the conventional digital photograph were taken (Nikon D7100 DSLR camera, UK). After 15 minutes, the photographic process was repeated and IR and Ultra Violet (UV) light modalities were used to 
register the reaction of the skin using a colour chart (Gretag MacBeth, ColorChecker, UK) besides the bite mark. Visual assessment of the images analysed the reaction of the skin of the subjects immediately after bite mark registration and after 15 minutes of waiting. Every single subject was instructed to contact the main author in case some bruising would appear within one week's time and photographs would be taken.

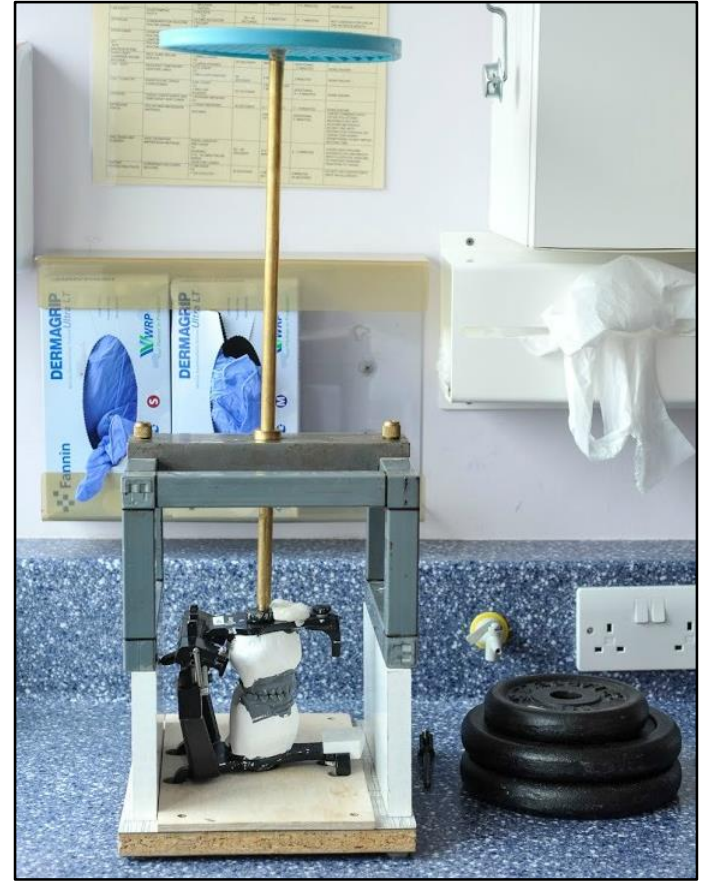

Fig. 1 - The mounted bite mark apparatus and respective weight plates.

Table 1 - Distribution of subjects according to type of skin tone, nationalities, age (years) and sex ( $F=$ female; $M=$ male).

\begin{tabular}{|c|c|c|c|c|}
\hline Subject & Type of skin tone & Nationalities & Age & Sex \\
\hline 1 & \multirow{3}{*}{$\begin{array}{c}\text { I - Pale white, ivory } \\
\text { or very fair }\end{array}$} & Scottish & 21 & $F$ \\
\hline 2 & & Scottish & 46 & $M$ \\
\hline 3 & & American & 24 & $F$ \\
\hline 4 & \multirow{3}{*}{ II - Fair } & Turkish & 26 & M \\
\hline 5 & & Italian & 41 & $F$ \\
\hline 6 & & Chinese & 24 & M \\
\hline 7 & \multirow{3}{*}{$\begin{array}{c}\text { III - Cream white } \\
\text { or beige }\end{array}$} & Indian & 25 & $\mathrm{~F}$ \\
\hline 8 & & Pakistani & 29 & $F$ \\
\hline 9 & & Indian & 25 & $F$ \\
\hline 10 & \multirow{3}{*}{ IV - Olive } & Indian & 25 & $F$ \\
\hline 11 & & Malaysian & 42 & $F$ \\
\hline 12 & & Thai & 30 & $\mathrm{~F}$ \\
\hline No & $\mathrm{V}$ - Brown or tan & & & \\
\hline 13 & \multirow{3}{*}{ VI - Black } & African & 26 & $M$ \\
\hline 14 & & African & 34 & $M$ \\
\hline 15 & & African & 42 & $M$ \\
\hline
\end{tabular}




\section{RESULTS}

The results for skin type I, II, III, IV, and $\mathrm{VI}$ were analysed according to the three different imaging modalities and the results for conventional photograph can be seen on table 2.

Table 2 - Results for conventional photograph according to type of skin tone.

\begin{tabular}{cr}
\hline Type of skin tone & Skin reaction \\
\hline I and II & Presence of red tooth marks and slight redness encompassing the \\
& $\begin{array}{c}\text { bite mark immediately after bite registration. After } 15 \text { minutes the redness } \\
\text { reduced in all subjects. No bruise detected. (fig. } 2 \text { and } 3 \text { ) }\end{array}$ \\
III, IV and VI & Presence of brown tooth marks immediately after bite registration \\
& and after 15 minutes in all subjects. No bruise detected. (fig.4, 5 and 6) \\
\hline
\end{tabular}

Results could not be appreciated for IR and UV light because these two imaging modalities should have been useful to

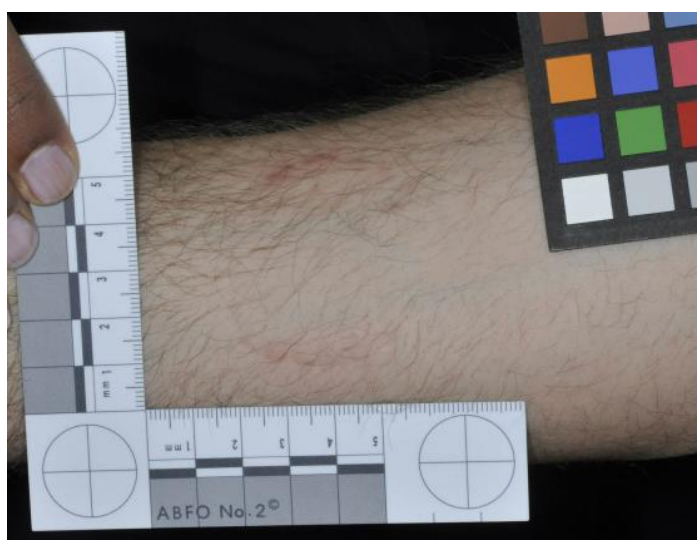

Fig 2 - Skin tone type I, subject 2.

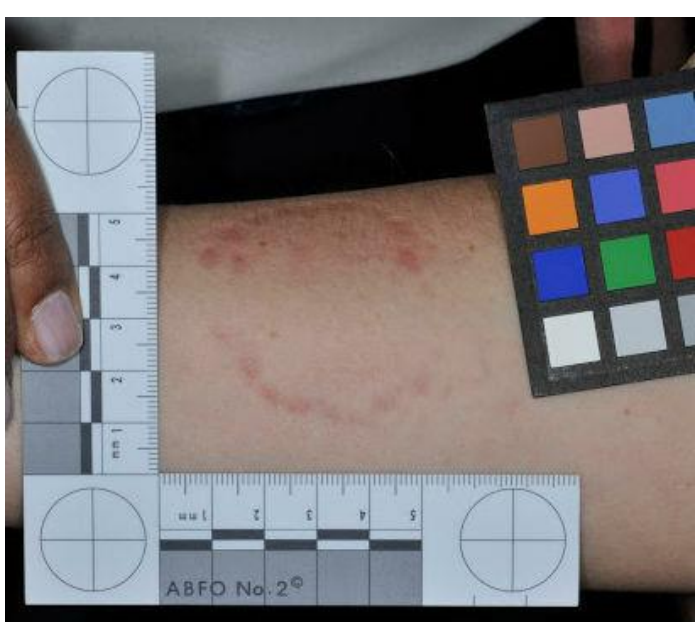

Fig 3 - Skin tone type II, subject 5. investigate bruising only after few days, but no subject reported the appearance of bruises.

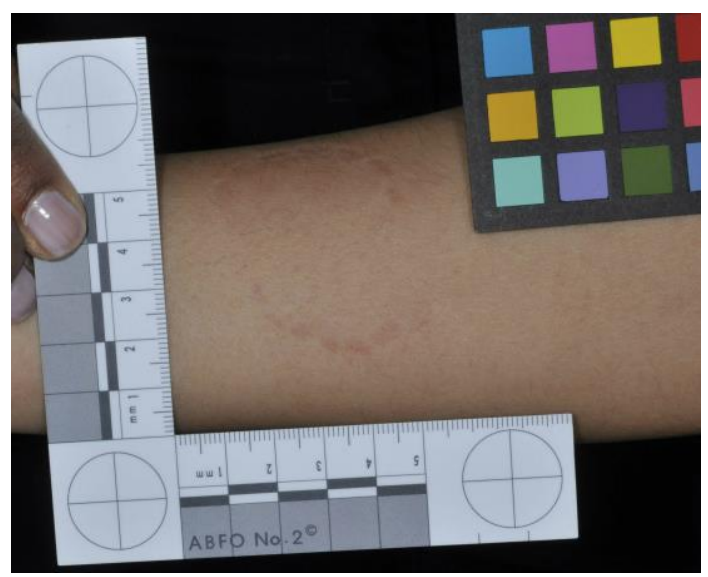

Fig 4 - Skin tone type III, subject 9.

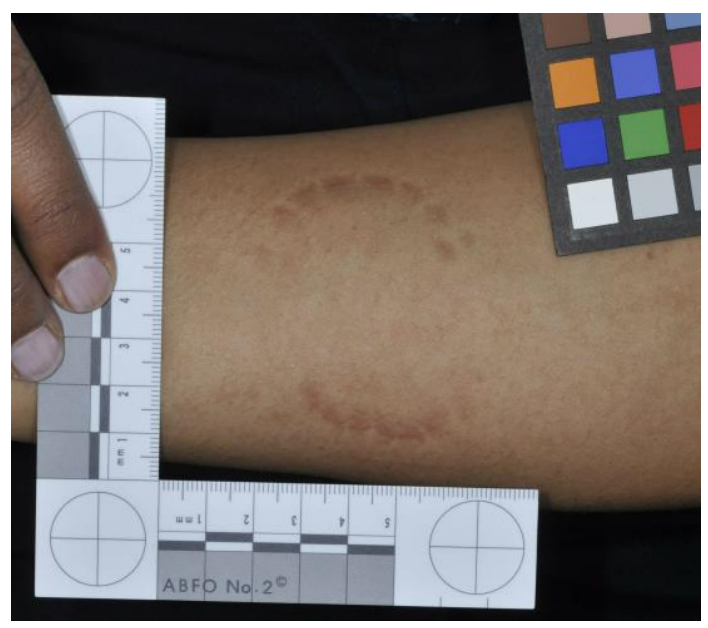

Fig 5 - Skin tone type IV, subject 10. 


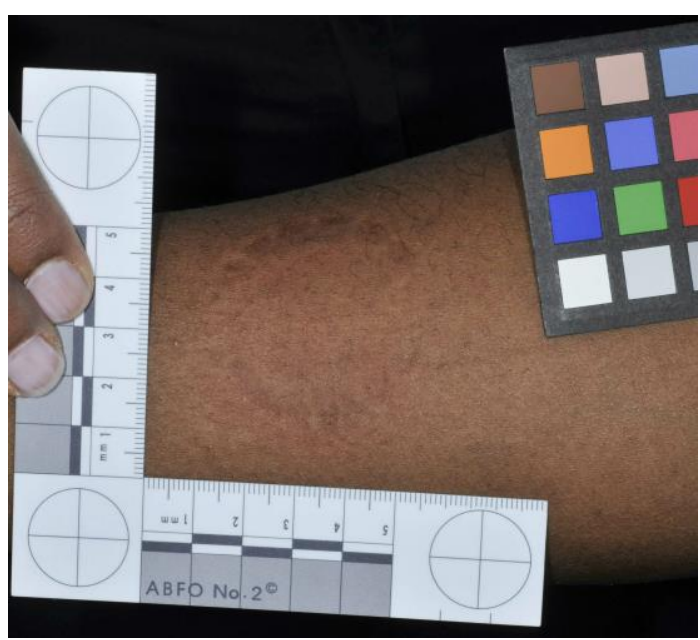

Fig 6 - Skin tone type VI, subject 14 .

\section{DISCUSSION}

The most visible teeth in a human bite mark are the front teeth including the central incisors, lateral incisors and the canines. Each type of tooth has class characteristics that are distinctively registered on skin due to tooth pressure, e.g. rectangular marks of incisors and oval shaped marks of canines ${ }^{3}$. Tooth pressure indicates pale areas representing incise edges and bruising that represent incisal margins. In this study, the anterior teeth were clearly visible in the images and premolars were seen in 6 subjects.Severity of bite mark is dependent upon duration, degree of force applied, depth of teeth penetration, intervening clothing and relative movements or struggle posed by the victim that can cause bruises ${ }^{10,11}$. These bruising show colour changes over a certain time as the injury undergoes a healing process in the skin of a living individual ${ }^{12}$. The dermal properties, anatomical site of the bite, age of the victim and weight can be responsible for the distortion produced by bite marks ${ }^{13}$. Body parts with loose skin bruises easily due to excess subcutaneous fat, lesser fibrous tissue and muscular tone ${ }^{14}$. More bruising is observed in children, females and elderly persons. More bruising in children is attributed to delicate, loosely attached skin and presence of subcutaneous fat. In an old person, more bruising is due to lesser elasticity and subcutaneous fat whereas easy bruising in females is due to delicate skin with more subcutaneous fat ${ }^{15}$.

Drag marks can also be seen in a bite mark and it depends upon the grip of the skin, placement of the bite mark, position of the biter or the position of the victim. In this study only a single subject demonstrated a drag mark but that probably could be due to lose grip of the bite since no bruising was seen in the subject.

The subjects selected were of different age groups, since it is a known fact that age affects the elasticity of the skin, skin becomes loose and adherent, in one of the volunteers a reddish discolouration was seen around the bite mark and the volunteer was in the age group of 40 years and above. Another finding was that males showed a less prominent mark than females since female volunteers had less tough skin than males irrespective of the skin tone and nationality. The bite marks were very prominent in subjects who were obese, especially in skin tone type I.

The bite force is created by the dynamic action of the masticatory system during the physiological act of chewing. The influencing physiologic and morphologic variables that affect the bite force are craniofacial morphology ${ }^{16-18}$, age ${ }^{19}, \operatorname{sex}^{19,20}$, periodontal support of teeth ${ }^{21}$, temporomandibular disorders, pain ${ }^{22}$ and dental status ${ }^{23}$. A study claimed that the maximum chewing force is $390 \mathrm{~kg}$, and the 
maximum bite force in people with intact natural dentition rarely exceeds $50-60 \mathrm{~kg}^{24}$. It is also considered that the values of the maximum bite force in men are greater than in women and tend to decrease with age $^{25}$. A research assessed biting forces of 59 men and 63 women and the results showed the mean values of the maximum bite force was of $522 \mathrm{~N}$ and $441 \mathrm{~N}$ [N = Newton] respectively ${ }^{26}$. Another studied showed that the maximum bite force in the frontal area is about $190 \mathrm{~N}$ in men and $50 \mathrm{~N}$ in women ${ }^{19}$. Hence, in this study, the chosen force applied was of 122.5.N [12.5 x 9.80] which is considered within the normal range.

Very few studies have used living human subjects for the simulation experiments and ethical concerns concerning biting of living volunteers has been a hindering factor ${ }^{9}$. If the time and force were increased may be the bite mark would be probably more severe and this pilot study could have shown more relevant results; therefore, one of the limitations of this study was the minimum force applied. Moreover, the time used to produce the injury and the anatomical location (and respective underlying tissues) have not contribute to the appearance of bruises.

\section{CONCLUSION}

The different types of skin tones did not affect the registration of bite mark applying a force of $122.5 . \mathrm{N}$ for 15 seconds in this sample.

\section{ACKNOWLEDGMENT}

The authors thank Mr. Sam Evans for assistance with photography service and for comments that greatly improved the methodology of this pilot study.

\section{RESUMO}

A análise das marcas de mordida é a parte mais desafiadora e complicada da Odontologia Forense. Vários fatores inter-relacionados, como a localização da mordida e a elasticidade da pele, complicam a análise da marca de mordida. A relação entre a marca de mordida e as propriedades bioquímicas da pele tem sido bem documentada, mas é preciso considerar a variedade de tons de pele como um fator a ser explorado. O objetivo deste estudo piloto foi analisar o aparecimento de marcas de mordida em 5 tipos diferentes de tons de pele de 15 indivíduos (6 homens e 9 mulheres) de 11 nacionalidades e idades entre 21 a 46 anos. Um par de modelos dentários impressos em 3D foi transferido para um aparelho mecânico para a produção de marcas de mordida experimentais usando $12,5 \mathrm{~kg}$ de peso. Modalidades de imagem digital como convencional, infravermelha e ultravioleta foram usadas para registrar as imagens da marca de mordida para posterior avaliação visual. Os diferentes tons de pele foram categorizados usando a escala de Fitzpatrick e uma cartela de cores foi usada para comparar as alterações na pele após 15 minutos de registro da mordida. De acordo com os resultados a força foi bem tolerada pelos sujeitos, produzindo uma marca de mordida bem definida, embora os homens mostraram uma marca menos proeminente do que as mulheres, independentemente do tom da pele e da nacionalidade. Nenhum hematoma ou mudanças significativas nas cores das marcas de mordida foram encontrados entre os indivíduos. Os diferentes tipos de tons de pele não afetaram o registro da marca de mordida aplicando uma força de $122,5 \mathrm{~N}$ por 15 segundos nesta amostra.

\section{PALAVRAS-CHAVE}

Odontologia legal; Mordedura; Tons de pele.

\section{REFERENCES}

1. Gorea RK, Jasuja OP, Abuderman AA, Gorea A. Bite marks on skin and clay: A comparative analysis. Egyptian Journal of Forensic Sciences. 2014; 4: 124-8. https://doi.org/10.1016/j.ejfs.2014.09.002.
2. Mânica S. Difficulties and limitations of using bite mark analysis in Forensic Dentistry - a lack of science. Rev Bras Odonto Leg RBOL. 2016; 3(2):83-91. http://dx.doi.org/10.21117/rbol.v3i2.8. 
3. Dorion RBJ. Bitemark Evidence. A Colour Atlas and Text. 2nd ed, 547-49 (CRC Press, 2011).

4. Sachdeva S. Fitzpatrick skin typing: Applications in dermatology. Indian journal of dermatology, venereology and leprology. 2009; $\quad$ 75(1):93-6. http://dx.doi.org/10.4103/0378-6323.45238.

5. Stephenson T, Y Bialas. Estimation of the age of bruising. Archives of Disease in Childhood. 1996; 74(1):53-5.

6. Golden GS. Standards and practices for bite mark photography. J Forensic Odontostomatol. 2011; 29: 29-37.

7. Evans $S$ et al. Guidelines for photography of cutaneous marks and injuries: a multiprofessional perspective. $\mathrm{J}$ Vis Commun Med. 2014; 37: 3-12. http://dx.doi.org/10.3109/17453054.2014.911 152.

8. Trefan L. et al. A comparison of four different imaging modalities - Conventional, cross polarized, infra-red and ultra-violet in the assessment of childhood bruising. J Forensic Leg Med. 2018; 59:30-5, http://dx.doi.org/10.1016/j.jflm.2018.07.015.

9. Chinni SS, Al-lbrahim A, Forgie AH. A simple safe, reliable and reproducible mechanism for producing experimental bite marks. J Forensic Odontostomatol 31, 22-29 (2013).

10. Stavrianos $C$ et al. Loss of the Ear Cartilage from a Human Bite. Research Journal of Medical Sciences. 2011; 20-24. http://dx.doi.org/10.3923/rimsci.2011.20.24.

11. Sweet D, Lorente M, Lorente JA, Valenzuela A, Villanueva E. An improved method to recover saliva from human skin: the double swab technique. J Forensic Sci. 1997; 42: 320-2.

12. Clark D. Practical forensic odontology. (Wright, 1992).

13. Vale GL, Sognnaes RF, Felando GN, Noguchi TT. Unusual three-dimensional bite mark evidence in a homicide case. J Forensic Sci. 1976; 21:642-52.

14. Solheim T, Leidal TI. Scanning electron microscopy in the investigation of bite marks in foodstuffs. Forensic Sci. 1975; 6:205-15.

15. Pretty IA. Forensic dentistry: 2. Bitemarks and bite injuries. Dent Update. 2008; 35, 48$50, \quad 53-44, \quad 57-48 \quad$ passim, http://dx.doi.org/10.12968/denu.2008.35.1.48

16. Ingervall B, Minder C. Correlation between maximum bite force and facial morphology in children. Angle Orthod. 1997; 67: 415-22; 423-14. http://dx.doi.org/10.1043/00033219(1997)067<0415:Cbmbfa>2.3.Co;2.
17. Shinogaya $T$ et al. Effects of ethnicity, gender and age on clenching force and load distribution. Clinical oral investigations. 2001; 5:63-8.

18. Waltimo A, Kononen M. A novel bite force recorder and maximal isometric bite force values for healthy young adults. Scandinavian journal of dental research. 1993; 101: 171-5.

19. Olthoff LW, van der Glas HW, van der Bilt A. Influence of occlusal vertical dimension on the masticatory performance during chewing with maxillary splints. Journal of oral rehabilitation. 2007; 34:560-5. http://dx.doi.org/10.1111/j.13652842.2007.01730.x.

20. Pereira-Cenci T, Pereira LJ, Cenci MS, Bonachela WC, Del Bel Cury AA. Maximal bite force and its association with temporomandibular disorders. Brazilian dental journal. 2007; 18:65-8.

21. Pereira LJ, Gaviao MB, Bonjardim LR, Castelo PM, van der Bilt A. Muscle thickness, bite force, and craniofacial dimensions in adolescents with signs and symptoms of temporomandibular dysfunction. European journal of orthodontics. $\quad 2007 ; \quad 29: 72-8$. http://dx.doi.org/10.1093/ejo/cjl055.

22. Sonnesen L, Bakke M, Solow B. Temporomandibular disorders in relation to craniofacial dimensions, head posture and bite force in children selected for orthodontic treatment. European journal of orthodontics. $2001 ; 23: 179-92$

23. Kaliyadan F, Manoj J, Venkitakrishnan S, Dharmaratnam AD. Basic digital photography in dermatology. Indian journal of dermatology, venereology and leprology. 2008; 74:532-6.

24. Apostolov N, Chakalov I, Drajev T. Measurement of the maximum bite force in the natural dentition with a gnathodynamometer. Medlnform. 2014; 1(2): 70-5.

http://dx.doi.org/10.18044/MedInform.201412 .70 .

25. Takaki $\mathrm{P}$, Vieira $\mathrm{M}$, Bommarito $\mathrm{S}$. Maximum bite force analysis in different age groups. International archives of otorhinolaryngology. 2014; 18:272-6. http://dx.doi.org/10.1055/s0034-1374647.

26. Braun S. et al. A study of bite force, part 1: Relationship to various physical characteristics. Angle Orthod. 1995; 65: 367$72 . \quad$ http://dx.doi.org/10.1043/00033219(1995)065<0367:Asobfp>2.0.Co;2. 